\title{
Religiosity and Chastity Among Single Young Adults and Married Adults
}

Sam A. Hardy

Brian J. Willoughby

Brigham Young University, brian.willoughby@byu.edu

Follow this and additional works at: https://scholarsarchive.byu.edu/facpub

Part of the Social and Behavioral Sciences Commons

\section{Original Publication Citation}

Hardy, S., \& Willoughby, B. J. (2017). Religiosity and chastity among single young adults and married adults. Psychology of Religion and Spirituality, 9, 285-295.

\section{BYU ScholarsArchive Citation}

Hardy, Sam A. and Willoughby, Brian J., "Religiosity and Chastity Among Single Young Adults and Married Adults" (2017). Faculty Publications. 5148.

https://scholarsarchive.byu.edu/facpub/5148

This Peer-Reviewed Article is brought to you for free and open access by BYU ScholarsArchive. It has been accepted for inclusion in Faculty Publications by an authorized administrator of BYU ScholarsArchive. For more information, please contact ellen_amatangelo@byu.edu. 


\title{
Religiosity and Chastity Among Single Young Adults and Married Adults
}

\author{
Sam A. Hardy and Brian J. Willoughby \\ Brigham Young University
}

\begin{abstract}
The purpose of the present study was to present theological, philosophical, and psychological arguments for chastity as a virtue, and then test an empirical model linking religiosity to outcomes by way of values about chastity. Specifically, we tested a mediation model linking religiosity to outcomes via chastity values (beliefs about the importance of waiting until marriage to have sex and importance of sex within marriage as a bonding experience). This model was tested with a sample of single young adults $(4,188)$ and a sample of married adults (2,531). Among single young adults, religiosity positively predicted abstinence beliefs, and abstinence beliefs negatively predicted unhappiness, risk taking, and risky sex. Among married adults, religiosity positively predicted both chastity values (i.e., importance of waiting until marriage to have sex and importance of sex within marriage as a bonding experience), while, in turn, both chastity values were positively linked to sexual frequency and sexual satisfaction, but only belief in marital sex as bonding was positively related to sexual satisfaction. Differences across religious affiliation were also discussed (comparing Catholics, Protestants, Latter-Day Saints, and those with no religious affiliation). We conclude that one way religious communities may promote chastity and positive psychosocial functioning is by teaching chastity values and providing structures to motivate and enable people to live consistently with them.
\end{abstract}

Keywords: religiosity, chastity, sex, young adult, virtue

Religion is theorized to influence behavior in part by providing moral directives regarding what actions are considered right and wrong (Smith, 2003). One behavioral domain for which religions typically provide such directives is sexuality, often in the form of proscriptions against premarital and extramarital sex and prescriptions toward marital sex (Regnerus, 2007). Religions promote these proscriptions and prescriptions on theological grounds, referring to the concept of "chastity." However, the idea that sexuality is a moral issue can also be built on philosophical grounds, arguing that chastity is a virtue (Carr, 2007). Although in the social sciences sexuality is generally not seen as a moral issue, but rather a matter of social conventions (Nucci \& Turiel, 1993) and public health (Shaw \& El-Bassel, 2014), here we make a case that sexuality can be seen as a moral issue on psychological grounds as well. While much research has linked religion to sexuality (Regnerus, 2007), little has done so looking at the mediating role of chastity values (i.e., moral values regarding sexual proscriptions and prescriptions). Thus, the purpose of the present paper was to make a conceptual case for chastity as a virtue, to present empirical findings that religions promote chastity, and that chastity values are predictive of a range of sexual and psychosocial outcomes, both maladaptive and adaptive. We tested these associations for both single young adults and married adults, and then examined whether the effects differed across religious affiliations.

Sam A. Hardy, Department of Psychology, Brigham Young University; Brian J. Willoughby, School of Family Life, Brigham Young University. The authors thank Joseph Moore for help with editing.

Correspondence concerning this article should be addressed to Sam A. Hardy, Department of Psychology, Brigham Young University, 1040 SWKT, Provo, UT 84602. E-mail: sam_hardy@byu.edu

\section{Theological Perspectives on Chastity}

Most religions see sexuality as a moral issue, making the case on theological grounds. The Catholic Church has articulated well its views on chastity as a virtue and provides an illustrative example of this principle. Such teachings can be found in the Catechism of the Catholic Church (1997), used to teach children and adult converts the basic doctrines of the faith. Sexuality is not just a physical act but involves union of body and spirit, and thus is a matter of personal integrity. Although God intended sex to be enjoyable (i.e., beneficial to individuals), it is primarily an altruistic act with two purposes: first, to bring married men and women together in love; second, to bring children into the world through procreation. While all acting on sexual desires outside of heterosexual marriage (e.g., masturbation, homosexuality, fornication, and adultery) is considered sinful, sex between a husband and wife is sacred. In fact, within heterosexual marriage sex is so sacred it is considered a "sacrament" (i.e., an important ceremonial act) intended by God to help sanctify, or make holy, the marital union. Thus, being chaste not only involves proscriptions against premarital and extramarital sex-it also involves prescriptions for using heterosexual, marital sex toward its sacred purposes of marital intimacy and the creation of life.

Given how central sexuality is to personal integrity and our relationships with others, according to the Catholic Church, it is an ethical issue of utmost importance (Catechism of the Catholic Church, 1997). Sexuality, to them, is a matter of personal integrity for religious individuals because it pertains to how appropriately they use God-given powers to love others, create life, and live in such a manner that our physical bodies and spirits are in harmony. Chastity is also considered a "moral virtue" falling under the virtue of temperance, given that it involves coordination and balance of reason and passion. Indeed, chastity is "an apprenticeship in self- 
mastery"-in other words, one of the best ways for humans to learn to control their thoughts, emotions, and actions (Catechism of the Catholic Church, 1997). Given that chastity is expressed in relationships it can also fall under the virtue of charity. In fact, chastity might be thought of as a "school" for learning and practicing charity. In short, the Catholic Church sees chastity as a fundamentally ethical matter relevant to the self-control (e.g., temperance) and attachment (e.g., charity) virtues.

Views on chastity are also quite similar (to that of the Catholic Church) in many other Christian traditions, such as Protestant Christianity and Mormonism (Regnerus, 2007). The Mormon church (officially The Church of Jesus Christ of Latter-Day Saints, or LDS church) has clear doctrines and official statements on chastity, often referred to as the "law of chastity," that are consonant with those of the Catholic Church (The Church of Jesus Christ of Latter-Day Saints, 2011). Specifically, chastity involves saving sexual behaviors for within the context of heterosexual marriage. Married sex between a man and woman is considered sacred, and intended to enrich individuals and couples, and bring children into families. Any use of sexuality outside of this context is seen as immoral. Chastity is a topic frequently taught on, spoken of, and written about in the LDS Church, and members of the church are regularly held accountable for their adherence to the law of chastity (Regnerus, 2007). The LDS church clearly sees chastity as a moral issue, as the terms "chastity" and "morality" are typically used synonymously, and breaking the law of chastity is considered immoral (Callister, 2014).

Given the vast number and diversity of Protestant faiths, Protestant views on chastity are more varied and less articulate, and there is no official unanimous statement on the matter. While mainline Protestant faiths tend to be more liberal regarding sexual norms (e.g., about masturbation, premarital sex, and sexual orientation), among "conservative" or "evangelical" Protestant faiths there is a focus on reserving acting on sexual desire for heterosexual marriage, and sexual behaviors outside of those boundaries are considered sinful and immoral (as with the Catholic and LDS churches; Regnerus, 2007). Such conservative views about sexuality within Protestant Christianity are evident in movements such as "True Love Waits," as well as popular media such at the highly influential book I Kissed Dating Goodbye (Harris, 1997).

\section{Philosophical Perspectives on Chastity}

In addition to theological claims regarding sexuality as a moral issue, the case can be made strictly on philosophical grounds that sexuality is an ethical matter, and chastity is a virtue (Carr, 2007). From an Aristotelian point of view, virtue is the state of being in balance between the two extremes of deficiency and excess of thoughts, emotions, and behaviors. Thus, sexual virtue, or chastity, means not overly suppressing or expressing one's sexual desires, but also having the practical wisdom (i.e., phronesis) to know when, where, in what ways, with whom, and to what extent sexual thoughts, feelings, and behaviors should be suppressed or expressed. Such a notion of sexual virtue seems to have elements of both types of Aristotelian virtues-virtues of self-control and virtues of attachment (Carr, 2007). Chastity might be seen as a virtue of self-control such as temperance, in that it involves the regulation of appetites, in this case, sexual desire. On the contrary, chastity is like the virtues of attachment such as charity and compassion in that it entails moral regard for and bonding with others. By this we mean things such as concerns about how having sex with a particular person in a particular context may help or hurt them physically and psychologically, as well as how it might help or hurt the relationship (empirical evidence on these outcomes is reviewed below, in the Psychological Perspectives on Chastity section).

Drawing on Aristotelian ideas, MacIntyre (2007) defined a virtue as "an acquired human quality the possession and exercise of which tends to enable us to achieve those goods which are internal to practices and the lack of which effectively prevents us from achieving any such goods" (p. 191). Sexuality can be seen as a domain of practice involving activities engaged in within relationships, and with internal goods, such as improving individual and relational well-being. As such, chastity, which is engaging in sexuality in an ethical way that maximizes individual and relational well-being, would be considered a virtue. Further, as noted above, this would also imply the wisdom to know which sexual thoughts, emotions, and behaviors in which contexts will be most facilitative of individual and relational well-being.

\section{Psychological Perspectives on Chastity}

In psychology, sexuality is most often seen as a public health issue, rather than a moral issue. First of all, delayed entrance into sexual activity is healthy because the earlier teens engage in sex, the more likely they are to get pregnant or contract sexually transmitted diseases (STDs; O'Donnell, O'Donnell, \& Stueve, 2001). Second, reduced number of lifetime sexual partners is healthy because having more sexual partners increases the risk of STDs (Shaw \& El-Bassel, 2014). Third, casual sex, or "hooking up," also poses greater risks of STDs (Olmstead, Roberson, Pasley, \& Fincham, 2015), and may negatively affect psychological wellbeing (Garcia, Reiber, Massey, \& Merriwether, 2012) and relationship satisfaction (Grov, Starks, Rendina, \& Parsons, 2014). Fourth, having multiple premarital sexual relationships is associated with a greater risk of subsequent divorce (Teachman, 2003). Fifth, early entrance into sex and cohabitation in adult couples is predictive of lower relationship quality in marriage (Sassler, Addo, \& Lichter, 2012). Sixth, extramarital sex is predictive of psychological distress (Carpenter, 2012) and divorce (DeMaris, 2013). In short, there are a number of negative physical, mental, and relational health outcomes of premarital and extramarital sexual behaviors which negatively affect individuals, families, and society. Thus, proscriptions (i.e., the "should nots") around premarital and extramarital sex have some empirical warrant based purely on public health concerns.

On the flip side, there is the positive side to sexuality. Engaging in some sexual behaviors in particular relational contexts can have healthy effects on individual and relational health and well-being. For instance, people in marriages that are sexually active are happier than those who are sexuality inactive (Donnelly, 1993). Furthermore, married couples who engage in more sex have fewer negative marital qualities and more positive marital qualities (Galinsky \& Waite, 2014). Also, interestingly, married women more easily adjust to pregnancy when they are able to maintain the quality of their sex life (Kisa, Zeyneloğlu, Yilmaz, \& Güner, 2014). Thus, prescriptions (i.e., the "shoulds") around sexuality, 
particularly among married couples, also have empirical warrant based on purely public health concerns.

In terms of sexuality as a moral issue, some psychological perspectives explicitly argue that it is not. For instance, social domain theory portrays sexuality as a matter of social convention rather than morality (Nucci \& Turiel, 1993). In other words, sexual behaviors such as premarital sex are not right or wrong based on universal moral principles, but are right or wrong depending on the norms of one's social contexts (e.g., cultures, religious communities, peer groups, and families), which can change (e.g., are dependent on authority figures). However, a typical way of defining morality in the social sciences is based on whether or not particular behaviors are fair or unfair, and whether they help or harm. In other words, morality is often seen as a matter of justice and care toward others, and perhaps toward oneself (Walker, Pitts, Hennig, \& Matsuba, 1995). Given evidence linking certain sexual behaviors in certain contexts (e.g., premarital and extramarital sex) to negative outcomes to individuals, families, and society (reviewed above), it follows that sexuality has implications for justice and care, and thus is a moral issue. As such, from a psychological perspective, sexual behaviors that are fair and helpful to individuals, families, and society, and minimize injustice and harm, might be considered a part of ethical sexuality, or chastity.

\section{Religiosity and Sexual Behavior}

A frequent outcome of religiosity studied in the literature is sexual behavior, likely given the salient norms around sexuality in religious communities (Regnerus, 2007). It is theorized that religiosity protects against precocious and risky sexual behavior, as well as extramarital sex, via numerous psychosocial mechanisms (Regnerus, 2007; Rostosky, Wilcox, Wright, \& Randall, 2004), such as increased self-regulation, greater social control and social capital, and less permissive attitudes about sex. Much of the research for teens has shown that age of onset into sexual activity is older for more religious teens than for others (Rostosky et al., 2004). In emerging adulthood, those who are more religious are less likely to cohabit (Village, Williams, \& Francis, 2010), and more likely to delay premarital sex (even in committed relationships; Barry, Willoughby, \& Clayton, 2015), or at least restrict sex to their future spouse (Uecker, 2008). Further, teens (Shaw \& El-Bassel, 2014) and never-married adults (Barkan, 2006) who are more religious tend to have fewer sexual partners. Lastly, married adults who are more religious are less likely to engage in extramarital sex (Atkins \& Kessel, 2008).

Most research on religion and sex, or even research on sex in general, has taken a negative focus, targeting the reduction of potentially unhealthy sexual behaviors (Arakawa, Flanders, Hatfield, \& Heck, 2013). Hence, little is known about the potential for religiosity to enhance positive or healthy sexuality. Of course, one way to understand such effects is to inversely interpret some of the findings reported above. For instance, instead of saying religious couples are less likely to engage in extramarital sex, we could interpret it as religious couples have greater sexual fidelity to their romantic partners, whether single (Uecker, 2008) or married (Atkins \& Kessel, 2008). However, beyond that there is also evidence suggesting that religious adults are more satisfied with their frequency of sex, and experience more physical and emotional satisfaction from sex (Iveniuk, O'Muircheartaigh, \& Cagney, 2016).
In short, there is evidence that religiosity is linked to healthy sexuality not only by reducing engagement in unhealthy sexual behaviors but also by improving the quality of sexuality.

\section{The Role of Valuing Chastity}

One important way in which religious institutions socialize morally relevant behavior, such as sex, is through the teaching of values about what is right and wrong (Smith, 2003). Indeed, research has found that values mediate relations between religiosity and prosocial behavior (Hardy \& Carlo, 2005), alcohol use (Brechting \& Carlson, 2015; Jankowski, Hardy, Zamboanga, \& Ham, 2013), drug use (Ford \& Hill, 2012), pornography use (Hardy, Steelman, Coyne, \& Ridge, 2013), and sex (Aalsma et al., 2013; Lefkowitz, Gillen, Shearer, \& Boone, 2004; Meier, 2003). However, more work is needed looking at how religiosity might influence chastity (i.e., abstention from maladaptive sexual behaviors and engagement in healthy marital sexuality) and related psychosocial outcomes (e.g., general health and well-being) by way of values specifically regarding chastity that are promoted by religious communities and doctrines (e.g., the importance of waiting until marriage to have sex and the role of sex as a bonding experience in marriage).

\section{The Moderating Role of Religious Affiliation}

Given the variation in the degree to which religious traditions teach conservative beliefs about chastity, and the extent to which they hold followers accountable for their level of chastity, the relations between religiosity, beliefs, and chastity might vary across religious affiliation. For instance, chastity values are more clearly delineated and uniform in the Catholic and LDS churches compared to many Protestant churches, particularly mainline Protestant faiths (Regnerus, 2007). On the contrary, accountability for chastity is more systematic in the LDS church compared with the Catholic church and Protestant churches-indeed LDS church members are regularly asked questions regarding their sexuality by their religious leaders (Regnerus, 2007). These differences in the doctrines and practices of religious communities are validated by findings suggesting that LDS teens are the most adaptive (e.g., fewest risk behaviors and most prosocial behaviors), followed by Protestant teens, then Catholic teens and unreligious teens (Regnerus, 2007; Smith \& Denton, 2005). Thus, religious affiliation may serve as a moderator of the mediation model linking religiosity to outcomes via chastity values. In essence, we anticipate stronger associations between religiosity and chastity values, and between chastity values and the outcomes, for the LDS individuals, followed by Protestants, then Catholics, then those with no religious affiliation.

\section{The Present Study}

Above, we presented theological, philosophical, and psychological perspectives on chastity as a virtue. In addition, we reviewed theory and research linking religiosity to chastity values, and chastity values to sexual behavior. Thus, we have outlined a mediation model linking religiosity to sexuality and psychosocial functioning by way of chastity values. Specifically, we hypothesized the more religious people would have more conservative 
views about chastity (belief in abstinence before marriage and that sex within marriage is a bonding experience), and that people with stronger chastity values have more adaptive outcomes. We tested this mediation model using a large sample of single young adults and a large sample of married adults.

This study contributes to prior literature in a number of ways. First, in the introduction above, we outlined psychological, philosophical, and theological arguments that sexuality is an ethical issue, and that chastity (i.e., ethical sexuality) can be considered a virtue in that it is linked to greater individual and relational well-being. To our knowledge, this integration has not been done previously in social sciences journals. Second, this is one of the first studies to look at chastity values (e.g., beliefs that premarital sex is ethically wrong, and that sex in marriage is important for bonding) as a mediator linking religiosity to sexual and psychosocial outcomes. Third, this is one of the first studies to look at a broad range of outcomes of chastity values, such as sexual outcomes (both proscriptive and prescriptive) and psychosocial outcomes (unhappiness and risk taking). Fourth, this is the first study to look at the moderating role of religious affiliation in linking religiosity to outcomes via chastity values.

\section{Method}

\section{Sample and Procedure}

Data for this portion of the study came from participants who took the READY and RELATE assessments online between 2009 and 2014 (Busby, Holman, \& Taniguchi, 2001). The RELATE assessment is a couple assessment designed to assess and provide feedback to those in romantic relationships. After taking the RELATE, couples are provided with feedback on their relationship strengths and weaknesses. Some participants were referred to the online site by their instructor in a university class, others by a relationship educator or therapist, and some participants found the instrument by searching for it on the web. Participants were instructed to complete the assessment alone and to not discuss their responses with their partner. Individuals who were not in a committed romantic relationship during the time they completed the online assessment were provided the READY assessment. The READY assessment is an online questionnaire that uses numerous measures to assess an individual's readiness for a committed romantic relationship. Participants were referred to READY through a variety of ways such as through family studies and psychology courses. The validity and reliability of the READY and RELATE scales have been assessed and established in previous studies (for details see Busby et al., 2001).

The current analytic sample included 4,188 $(M$ age $=24.08$, $S D=8.03 ; 72.7 \%$ female; $86 \%$ European American) individuals not in a committed relationship and 2,531 $(M=32.53, S D=$ $10.52 ; 58.6 \%$ female; $86 \%$ European American) within a marital relationship. The READY sample was primarily made up of college students $(69 \%)$ who identified as heterosexual $(98 \%)$. As one of our main objectives was to examine associations across different religious groups, only those individuals who identified as Catholic $($ READY $=11.6 \%$; RELATE $=11.6 \%)$, Protestant $($ READY $=20.6 \% ;$ RELATE $=23.1 \%)$, Latter-Day Saint $(L D S$; READY $=60.2 \%$; RELATE $=53.4 \%$ ) or reported no religious affiliation $($ READY $=7.6 \%$; RELATE $=11.8 \%)$ were included in the sample. Those with other identified religious affiliations did not comprise groups with adequate sample sizes for analysis.

\section{Measures}

For the READY portion of the study, five latent variables were modeled using between two and five indicator items.

Religiosity. Importance of and involvement in religion and spirituality was measured by two items rated from 1 (never) to 5 (very often): "Spirituality is an important part of my life;" "How often do you pray (commune with a higher power)?" Both standardized factor loadings were above $.80(r=.82, p<.001)$.

Chastity values-Belief in premarital sexual abstinence. Strength of conservative beliefs about premarital sexual abstinence was assessed with three items $(\alpha=.96)$ rated from 1 (strongly disagree) to 5 (strongly agree): “As long as we're in a committed relationship, sexual intercourse is acceptable before marriage (reverse coded)," "Couples should wait until they are married to have sex," and "I am waiting until I am married to have sex." All standardized factor loadings were above .90 .

Unhappiness. Feelings of unhappiness were assessed using three items $(\alpha=.83)$ asking participants to indicate how often, from 1 (never) to 5 (very often), the following phrases described them: "sad and blue," "feel hopeless," and "depressed." All standardized factor loadings were above .70 .

Risk taking. Engagement in the following five risk behaviors ( $\alpha=.77$ ) in the last month was assessed from 0 (never) to 5 (almost every day): drink alcohol, drink more than four drinks within two hours, use prescription medications without a doctor's permission, use marijuana, use other illegal drugs (cocaine, heroin, etc.), and ride in a car driven by someone who had been drinking. Standardized factor loadings ranged from .49 to .94 .

Risky sexual behaviors. Involvement in the following two risky sexual behaviors in the last year was assessed from 0 (never) to 5 (every day or almost every day): "Engage in sexual intercourse without using a condom?" and "Hook-up sexually with someone you just met?" Both standardized factor loadings were above .50 , $r=.32, p<.001$.

For the RELATE portion of the study, one latent variable was modeled with two indicator items (religiosity), and four observed single-item variables were modeled.

Religiosity. This was assessed by the same two items as the READY sample. Both items had standardized factor loadings above .90 .

Chastity values-Belief in premarital sexual abstinence. Strength of beliefs about premarital sexual abstinence was measured using the item, "As long as we're in a committed relationship, sexual intercourse is acceptable before marriage (reverse coded)," rated from 1 (strongly disagree) to 5 (strongly agree).

Chastity values-Belief in marital sex as bonding. Strength of beliefs about sex as a bonding experience in marriage was assessed using the item, "Sexual intercourse is the most bonding experience you can have in marriage," rated from 1 (strongly disagree) to 5 (strongly agree).

Sexual frequency. Frequency of sexual intercourse was assessed by the following item, rated from 1 (never) to 7 (more than once a day): "About how often do you currently have sex with your partner?" 
Sexual satisfaction. Satisfaction with sex in committed relationships was assessed by one item, rated from 1 (never) to 5 (very often): "Do you find the sexual relationship with your partner satisfactory?"

\section{Analysis Plan}

Descriptive statistics were obtained using SPSS. The primary analyses were conducted using Mplus (Muthén \& Muthén,19982012). Model parameters were estimated using full information maximum likelihood estimation, which capitalizes on available data to estimate parameters, so all cases with data on at least one variable were included in the analysis. As indicators of model fit (Brown, 2006), we used the chi-square $\left(\chi^{2}\right)$ statistic, the rootmean-square-error of approximation and standardized root-meansquare residual (RMSEA and SRMR, respectively; values below .05 indicate good fit, below .08 indicate moderate fit, and below .10 indicating mediocre fit), and the comparative fit index (CFI; values above .95 indicate good fit, and values above .90 indicate moderate fit). The primary analyses consisted of using structural equation modeling to estimate measurement models and then mediation models of religiosity predicting outcomes by way of chastity values, separately, for the samples of singles and married couples. Then, within each sample we tested whether the structural paths in the mediation models varied depending on religious affiliation.

\section{Results}

\section{Preliminary Analyses}

Descriptive statistics by religious affiliation for the total sample, separately for the singles and married couples, are presented in Table 1 . We conducted multivariate analyses of variance to compare religious affiliations on all study variables within each sample (results are also reported in Table 1). The trends generally followed prior research (e.g., Smith \& Denton, 2005) in that LDS participants had the highest levels of religiosity, the strongest chastity values, and the most adaptive sexual and psychosocial outcomes, followed by Protestants, then Catholics, then those with no religious affiliation (although there were several exceptions to this pattern).

Next, we ran measurement models to assess factor structures of the latent variables and bivariate correlations between all study variables. These models included all the latent and observed study variables and all of the possible covariances between them. All bivariate correlations in both samples were statistically significant (as shown in Table 2 for singles and Table 3 for married couples). The measurement model for the singles adequately fit the data, $\chi^{2}(65)=1718.99, p<.001$, RMSEA $=.08$, CFI $=.96$, SRMR $=$ .04. Religiosity and chastity values (belief in premarital sexual abstinence) were positively related to each other and negatively associated with the outcomes of unhappiness, risk taking, and risky sexual behaviors. For the model with married participants, only one latent variable (religiosity) with two indicators was utilized. Therefore, no preliminary measurement model was run. However, the two indicators of religiosity did load well on the latent variable (>.90). Religiosity was positively related to beliefs in premarital sexual abstinence, beliefs that marital sex is bonding, sexual satisfaction, and sexual frequency. Belief in premarital sexual abstinence was likewise positively related to the belief that marital sex is bonding, sexual satisfaction, and sexual frequency. Lastly, the belief that marital sex is bonding is positively correlated with sexual satisfaction and sexual frequency.

\section{Primary Analyses for Singles}

The proposed mediation model of religiosity predicting outcomes via chastity values was tested by estimating a structural equation model with gender and age as covariates. We compared a model that included the direct effects from religiosity to the outcomes to one where these paths were omitted. All fit indices (RMSEA, CFI, TLI, and SRMR) were the same for the two models, while the chi-square difference test was significant, $\left.\Delta \chi^{2}(2)=18.40, p<.001\right)$. Given that chi-square tests are oversensitive for large sample sizes, we elected to keep the most parsimonious model, and thus excluded the direct links between religiosity and outcomes. Including or excluding these direct effects did not change the significance of any other pathways in the model.

Table 1

Means and Standard Deviations on Main Study Variables by Religious Affiliation

\begin{tabular}{|c|c|c|c|c|c|c|c|c|c|c|}
\hline \multirow[b]{2}{*}{ Variable } & \multicolumn{2}{|c|}{ Catholic } & \multicolumn{2}{|c|}{ Protestant } & \multicolumn{2}{|c|}{ Latter-Day Saint } & \multicolumn{2}{|c|}{ None } & \multicolumn{2}{|c|}{ Total sample } \\
\hline & $M$ & $S D$ & $M$ & $S D$ & $M$ & $S D$ & $M$ & $S D$ & $M$ & $S D$ \\
\hline \multicolumn{11}{|l|}{ Singles } \\
\hline Religiosity & $3.56^{\mathrm{a}}$ & 1.06 & $4.03^{\mathrm{b}}$ & .99 & $4.73^{\mathrm{c}}$ & .53 & $2.22^{\mathrm{d}}$ & 1.10 & 4.26 & 1.05 \\
\hline Chastity values $\mathrm{AB}$ & $2.41^{\mathrm{a}}$ & 1.22 & $2.92^{\mathrm{b}}$ & 1.36 & $4.86^{\mathrm{c}}$ & .45 & $1.73^{\mathrm{d}}$ & .80 & 4.15 & 1.36 \\
\hline Unhappiness & $2.35^{\mathrm{a}}$ & .69 & $2.31^{\mathrm{ab}}$ & .68 & $2.28^{\mathrm{b}}$ & .68 & $2.58^{\mathrm{c}}$ & .79 & 2.33 & .70 \\
\hline Risk taking & $.80^{\mathrm{a}}$ & .74 & $.63^{\mathrm{b}}$ & .61 & $.04^{\mathrm{c}}$ & .20 & $.79^{\mathrm{a}}$ & .70 & .27 & .53 \\
\hline Risky sex & $.47^{\mathrm{a}}$ & .76 & $.45^{\mathrm{a}}$ & .70 & $.04^{\mathrm{b}}$ & .24 & $.57^{\mathrm{c}}$ & .79 & .18 & .50 \\
\hline \multicolumn{11}{|l|}{ Married } \\
\hline Religiosity & $3.49^{\mathrm{a}}$ & 1.10 & $3.97^{\mathrm{b}}$ & 1.05 & $4.58^{\mathrm{c}}$ & .65 & $2.10^{\mathrm{d}}$ & 1.01 & 4.02 & 1.18 \\
\hline Chastity values $\mathrm{AB}$ & $2.23^{\mathrm{a}}$ & 1.04 & $3.03^{\mathrm{b}}$ & 1.37 & $4.73^{\mathrm{c}}$ & .69 & $1.67^{\mathrm{d}}$ & .79 & 3.69 & 1.51 \\
\hline Chastity values SB & $2.95^{\mathrm{a}}$ & 1.07 & $2.96^{\mathrm{a}}$ & 1.07 & $3.25^{\mathrm{b}}$ & 1.08 & $2.82^{\mathrm{c}}$ & 1.01 & 3.10 & 1.08 \\
\hline Sexual satisfaction & $3.42^{\mathrm{a}}$ & 1.22 & $3.61^{\mathrm{a}}$ & 1.08 & $4.07^{\mathrm{b}}$ & 1.02 & $3.48^{\mathrm{a}}$ & 1.10 & 3.84 & 1.10 \\
\hline Sexual frequency & $3.40^{\mathrm{a}}$ & 1.30 & $3.67^{\mathrm{b}}$ & 1.31 & $4.32^{\mathrm{c}}$ & 1.25 & $3.47^{\mathrm{a}}$ & 1.30 & 3.96 & 1.34 \\
\hline
\end{tabular}

Note. Differing superscripts signify significant mean differences $(p<.05)$. Chastity values $\mathrm{AB}=$ belief that abstinence from premarital sex is best; Chastity values $\mathrm{SB}=$ belief that sex in marriage is a bonding experience. 
Table 2

Bivariate Correlation Matrix for READY Sample

\begin{tabular}{lccccr}
\hline \multicolumn{1}{c}{ Variable } & 1 & 2 & 3 & 4 & 5 \\
\hline 1. Religiosity & 1 & & & & \\
2. Chastity values AB & $.79^{* * * * *}$ & 1 & & & \\
3. Unhappiness & $-.19^{* * * *}$ & $-.11^{* * * * *}$ & 1 & & \\
4. Risk taking & $-.57^{* * * *}$ & $-.65^{* * * *}$ & $.13^{* * * *}$ & 1 & \\
5. Risky sex & $-.40^{* * * *}$ & $-.49^{* * * *}$ & $-.11^{* * * *}$ & $-.63^{* * * *}$ & 1 \\
\hline
\end{tabular}

Note. Chastity values $\mathrm{AB}=$ belief that abstinence from premarital sex is best.

**** $p<.001$.

The final model without direct effects (Figure 1) adequately fit the data, $\chi^{2}(90)=2816.63, p<.001$, RMSEA $=.09$, CFI $=.94$, $\mathrm{SRMR}=.07$. Religiosity positively predicted chastity values (belief in premarital sexual abstinence; $\beta=.80, p<.001$ ), while chastity values negatively predicted unhappiness $(\beta=-.12, p<$ $.001)$, risk-taking $(\beta=-.82, p<.001)$, and risky sexual behaviors $(\beta=-.70, p<.001)$. The model accounted for a large amount of variance in chastity values $\left(R^{2}=.64\right)$, risk taking $\left(R^{2}=\right.$ $.67)$, and risky sex $\left(R^{2}=.49\right)$, but only a small amount of the variance in unhappiness $\left(R^{2}=.02\right)$.

Indirect effects of religiosity on the outcomes via chastity values as a mediator were tested using a bootstrapping estimation method with 5,000 draws. Results suggested significant and negative indirect effects from religiosity to unhappiness $(\beta=-.10, p<.001$, $95 \% \mathrm{CI}[-.12,-.07])$, risk taking $(\beta=-.66, p<.001,95 \% \mathrm{CI}$ $[-.68,-.63])$, and risky sexual behaviors $(\beta=-.56, p<.001$, $95 \%$ CI $[-.64,-.47])$. Thus the indirect effect to unhappiness was small, while those to risk taking and risky sexual behaviors were large.

We next compared the structural paths of this model across religious affiliations. Structural invariance was examined for each of four religious groups (Catholic, Protestant, LDS, and no affiliation). This was accomplished by fitting a configural model for each two-group comparison where structural pathways were allowed to vary freely. Specific pathways were then constrained to be equal across groups and model fit was compared to explore which model was a better fit for the data. Table 4 summarizes the specific path coefficients for each religious group.

All religious subgroups had a positive association between religiosity and chastity values (belief in premarital sexual abstinence). Chastity values were only negative associated with unhappiness for LDS, but negatively predicted risk taking for all four religious groups. Finally, chastity values were significantly associated with fewer risky sexual behaviors for all groups except those with no religious affiliation.

Based on invariance tests, a lack of invariance was found between Catholics and LDS in the direct effect between chastity values and unhappiness, $\left.\Delta \chi^{2}(1)=33.31, p<.001\right)$. While for Catholics, the association was not significant $(\beta=.05, p=.37)$, for LDS, the association was negative and significant $(\beta=-.18$, $p<.001)$. LDS and those with no religious affiliation also lacked invariance, $\left.\Delta \chi^{2}(1)=12.95, p<.001\right)$ in the path between chastity values and unhappiness, again with the association being significant for LDS but not for those with no affiliation $(\beta=.07, p=$ .22 ). A final lack of invariance was found between chastity values and unhappiness between LDS and Protestants, $\Delta \chi^{2}(1)=34.27$ $p<.001$, with LDS having a negative association, but Protestants having no association between the variables $(\beta=.02, p=.72)$. In short, the negative link between chastity values and unhappiness was largely unique to LDS. Only one other invariance test was significant, that for the association between chastity values and risky sexual behaviors. LDS $(\beta=.62, p<.001)$ and those with no affiliation $(\beta=-.06, p=.59)$ significantly differed, $\Delta \chi^{2}(1)=$ $7.55, p=.006)$.

\section{Primary Analyses for Married Sample}

For married couples we estimated structural equation models to explore indirect effects from religiosity to outcomes through the two chastity values (belief in premarital sexual abstinence and belief in marital sex as bonding), with age and gender included as covariates. Again, we compared a model with direct effects from religiosity to outcomes to one with the direct effects omitted. The model with direct effects better fit the data, $\Delta \chi^{2}(2)=67.96, p<$ $.01(\Delta \mathrm{RMSEA}=0 ; \Delta \mathrm{CFI}=.01 ; \Delta \mathrm{SRMR}=.01 ;$ Figure 2$)$. The final model with the direct effect adequately fit the data, $\chi^{2}(12)=$ 201.95, $p<.001$, RMSEA $=.08, \mathrm{CFI}=.97, \mathrm{SRMR}=.05$.

Religiosity positively predicted beliefs about premarital sexual abstinence $(\beta=.72, p<.001)$ and marital sex as bonding $(\beta=$ $.18, p<.001)$. Religiosity was also directly linked to sexual frequency $(\beta=.18, p<.001)$ and sexual satisfaction $(\beta=.25$, $p<.001)$. Both chastity values were predictive of the outcomes. While belief in premarital sexual abstinence did not have a significant association with sexual satisfaction, it was positively predictive of sexual frequency $(\beta=.09, p=.001)$. Belief that marital sex is bonding was positively predictive of both greater sexual satisfaction $(\beta=.07, p<.001)$ and higher sexual frequency $(\beta=$ $.06, p=.001)$. The model predicted moderate to large amounts of variance for both sexual satisfaction $\left(R^{2}=.12, p<.001\right)$ and sexual frequency $\left(R^{2}=.23, p<.001\right)$.

To explore indirect effects, bootstrapping estimation was again used with 5,000 draws. Significant indirect effects were found for religiosity through both chastity values (belief in premarital sexual abstinence and in marital sex as bonding). Religiosity had a positive indirect effect through abstinence to sexual frequency $(\beta=$ $.07, p=.002,95 \%$ CI $[.03, .12])$. Religiosity also had a significant indirect effect through the belief that marital sex is bonding to both sexual frequency $(\beta=.01, p=.002,95 \% \mathrm{CI}[.004, .018])$ and sexual satisfaction $(\beta=.01, p=.001,95 \%$ CI $[.005, .021])$. All indirect effects were small.

Table 3

Bivariate Correlation Matrix for RELATE Sample

\begin{tabular}{lccccr}
\hline \multicolumn{1}{c}{ Variable } & 1 & 2 & 3 & 4 & 5 \\
\hline 1. Religiosity & 1 & & & & \\
2. Chastity values AB & $.69^{* * * *}$ & 1 & & & \\
3. Chastity values SB & $.14^{* * * *}$ & $.13^{* * * *}$ & 1 & & \\
4. Sexual satisfaction & $.25^{* * * *}$ & $.22^{* * *}$ & $.14^{* * * *}$ & 1 & \\
5. Sexual frequency & $.24^{* * * *}$ & $.26^{* * * *}$ & $.17^{* * * *}$ & $.58^{* * * *}$ & 1 \\
\hline
\end{tabular}

Note. Chastity values $\mathrm{AB}=$ belief that abstinence from premarital sex is best; Chastity values $\mathrm{SB}=$ belief that sex in marriage is a bonding experience.

$* * * * 0.001$. 


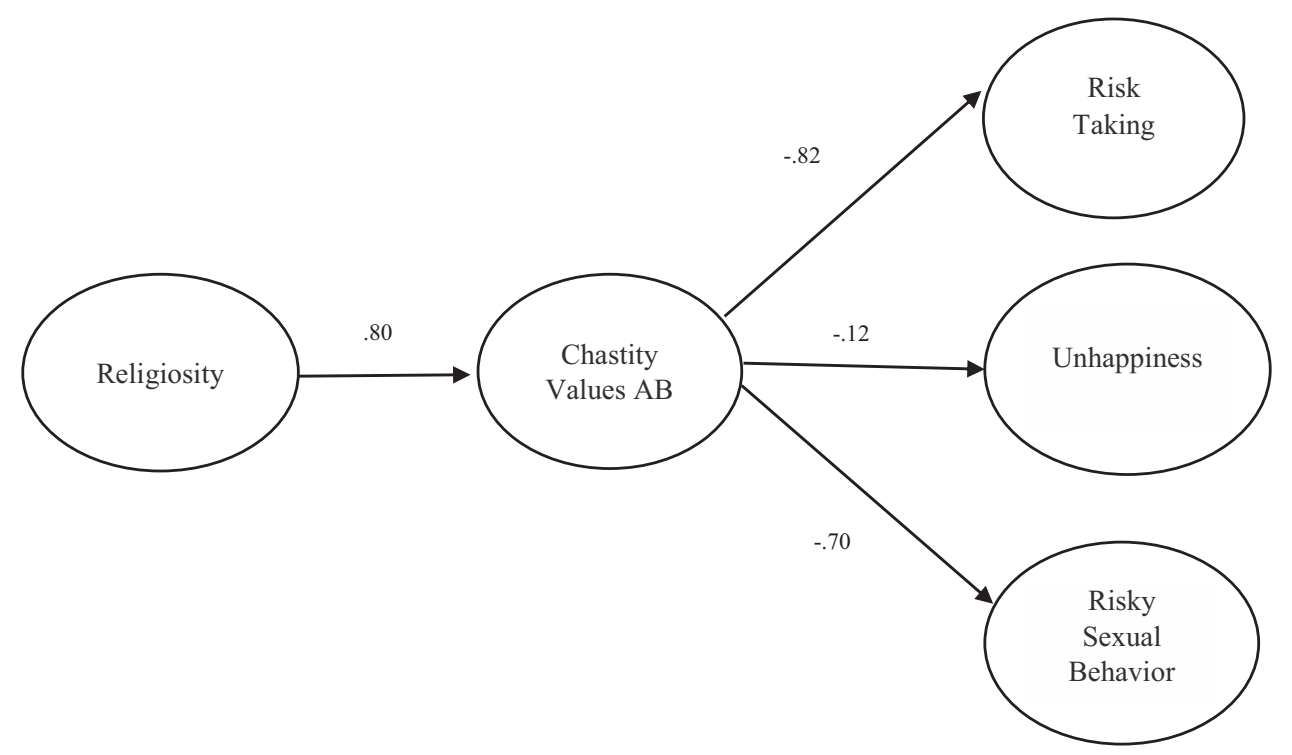

Figure 1. Structural path model for associations between religiosity, abstinence beliefs, and outcomes among single participants. Solid lines indicate significant associations $(p<.001)$. Controls (gender, age), indicator items, and error terms are omitted for ease of readability. Chastity Values $\mathrm{AB}=$ belief that abstinence from premarital sex is best.

We next explored model effects by religious affiliation (Table 5). Religiosity positively predicted belief in premarital sexual abstinence for all four religious groups, but only predicted the belief that marital sex is bonding for Protestants and LDS. Religiosity was predictive of sexual satisfaction for all three religions (Catholic, Protestant, and LDS), but was only predictive of sexual frequency for Catholics and LDS. Belief in premarital sexual abstinence did not predict sexual frequency and sexual satisfaction for any group. However, LDS had a positive but small association between the belief that marital sex is bonding and sexual frequency, while both Protestants and LDS had a positive link between this belief and sexual satisfaction.

\section{Discussion}

The purpose of the current paper was to present philosophical, religious, and psychological arguments for chastity as a virtue; to empirically demonstrate that religiosity promotes chastity values; and that such chastity values are predictive of a range of psychosocial and sexual outcomes. We tested these associations among single young adults and married adults, and examined whether the effects differed across religious affiliations. In both samples we found partial support for our hypothesized mediation model of religiosity predicting adaptive sexual and psychosocial outcomes via chastity values. Further, in both samples relations among study variables differed in interesting ways depending on religious affiliation.

In line with prior research, people who were more religious held more conservative views about sexuality (Meier, 2003; Regnerus, 2007; Smith, 2003), such as believing more strongly that individuals should wait until they are married to have sex, as well as feeling that sex is an important bonding experience within marriage. This finding is likely no surprise, given that most religions have conservative doctrines and social norms regarding sexuality before, within, and outside of the marital relationship (Regnerus, 2007). However, it does provide evidence that the messages being conveyed in religious communities regarding chastity are getting internalized, and that this internalization is directly proportional to the level of religious commitment and involvement. Nevertheless, given the relative strength of links between religiosity and abstinence beliefs as compared with that between religiosity and no-

Table 4

Summary of Path Coefficients for Models by Religious Subgroup for READY

\begin{tabular}{|c|c|c|c|c|c|c|c|c|}
\hline \multirow[b]{2}{*}{ Paths } & \multicolumn{2}{|c|}{ Catholic } & \multicolumn{2}{|c|}{ Protestant } & \multicolumn{2}{|c|}{ Latter-Day Saint } & \multicolumn{2}{|c|}{ None } \\
\hline & $\beta$ & $p$ & $\beta$ & $p$ & $\beta$ & $p$ & $\beta$ & $p$ \\
\hline Religiosity $\rightarrow$ Chastity values $\mathrm{AB}$ & $.54^{* * * *}$ & $<.001$ & $.60^{* * * *}$ & $<.001$ & $.68^{* * * *}$ & $<.001$ & $.34^{* * * *}$ & $<.001$ \\
\hline Chastity values $\mathrm{AB} \rightarrow$ Unhappiness & .05 & .367 & .02 & .72 & $-.18^{* * * *}$ & $<.001$ & .07 & .22 \\
\hline Chastity values $\mathrm{AB} \rightarrow$ Risk taking & $-.45^{* * * *}$ & $<.001$ & $-.60^{* * * *}$ & $<.001$ & $-.58^{* * * *}$ & $<.001$ & $-.27^{* * * *}$ & $<.001$ \\
\hline Chastity values $\mathrm{AB} \rightarrow$ Risky sex & $-.27^{* * * *}$ & .001 & $-.62^{* * *}$ & $<.001$ & $-.62^{* * * *}$ & $<.001$ & -.06 & .59 \\
\hline
\end{tabular}

Note. Chastity values $\mathrm{AB}=$ belief that abstinence from premarital sex is best.

**** $p<.001$. 


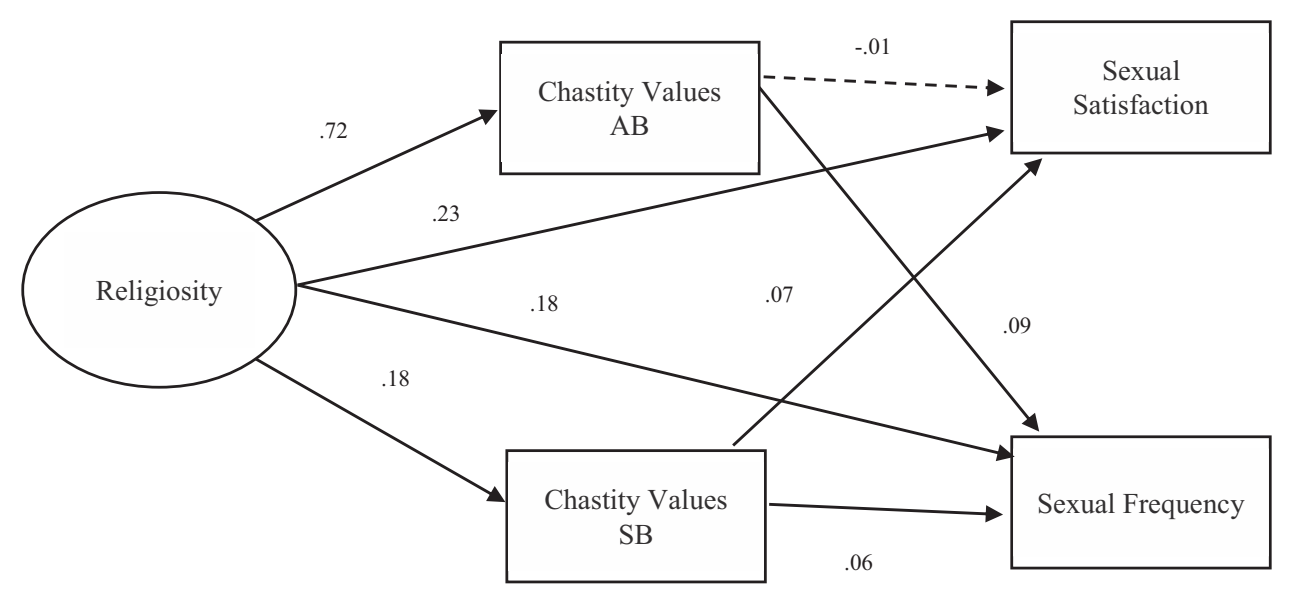

Figure 2. Structural path model for associations between religiosity, abstinence beliefs, belief that sex is bonding in marriage, and outcomes among married participants. Solid lines indicate significant associations ( $p \leq$ .001). Controls (gender, age), indicator items, and error terms are omitted for ease of readability. Chastity Values $\mathrm{AB}=$ belief that abstinence from premarital sex is best; Chastity Values $\mathrm{SB}=$ belief that sex in marriage is a bonding experience.

tions of sex as a bonding experience, it is possible that religious communities are more effective at teaching proscriptions about sexuality than prescriptions (i.e., "should nots" are more salient than "shoulds"; McMurdie, Dollahite, \& Hardy, 2013; Regnerus, 2007). Further research is needed on predictors and outcomes of prescriptions about sexuality.

The role of religiosity in chastity values (beliefs in premarital sexual abstinence and marital sex as bonding) was generally consistent across religious affiliation (Catholic, Protestant, and LDS). This uniform relationship was particularly true for belief in premarital sexual abstinence; religiosity had strong positive associations with abstinence beliefs across all four religious groups for both age groups. On the contrary, religiosity predicted views about marital sex as bonding only among Protestant and (LDS groups in the married adult sample; although it was marginally significant for Catholics). Thus, organized religions, particularly Protestant and LDS religions, may provide a platform for helping people appreciate the relational benefits of marital sex (implicitly understanding chastity as a virtue of attachment; Carr, 2007). As further evidence of this in the present study, the LDS group by far had the strongest chastity values, followed by the Protestant group, and then the Catholic group.

The present study also found that chastity values (beliefs about the importance of sexual abstinence before marriage, and feelings that sex is an important bonding experience within marriage) were generally linked to adaptive outcomes. Specifically, we found that single young adults with greater chastity values (belief in premarital sexual abstinence) were happier, engaged in less risk taking, and engaged in less risky sex. Further, married adults with stronger chastity values (beliefs in premarital sexual abstinence and marital sex as bonding) had sex more frequently, while those with stronger beliefs in marital sex as bonding also were more satisfied with their sex life. This, to some extent, goes against the popular notion that people with strong chastity values are overly restrictive (Regnerus, 2011), because not only are people who strongly believe in chastity less likely to engage in premarital sex, but, they are happy with their lifestyle, with some evidence of a stronger sex life when they do get married. This may be because such individuals see marital sexuality as "sanctified" or sacred, and thus imbued with more meaning than do less religious couples (Hernandez, Ma-

Table 5

Summary of Path Coefficients for Models by Religious Subgroup for RELATE

\begin{tabular}{|c|c|c|c|c|c|c|c|c|}
\hline \multirow[b]{2}{*}{ Paths } & \multicolumn{2}{|c|}{ Catholic } & \multicolumn{2}{|c|}{ Protestant } & \multicolumn{2}{|c|}{ Latter-Day Saint } & \multicolumn{2}{|c|}{ None } \\
\hline & $\beta$ & $p$ & $\beta$ & $p$ & $\beta$ & $p$ & $\beta$ & $p$ \\
\hline Religiosity $\rightarrow$ Chastity values $\mathrm{AB}$ & $.28^{* * * *}$ & $<.001$ & $.61^{* * * *}$ & $<.001$ & $.53^{* * * *}$ & $<.001$ & $.27^{* * * *}$ & $<.001$ \\
\hline Religiosity $\rightarrow$ Chastity values SB & .11 & .09 & $.10^{*}$ & .03 & $.08^{* * *}$ & .007 & -.03 & .64 \\
\hline Religiosity $\rightarrow$ Sexual satisfaction & $.20^{* *}$ & .003 & $.13^{*}$ & .03 & $.27^{* * * *}$ & $<.001$ & .07 & .25 \\
\hline Religiosity $\rightarrow$ Sexual frequency & $.23^{* * * *}$ & $<.001$ & .08 & .20 & $.17^{* * * *}$ & $<.001$ & .08 & .12 \\
\hline Chastity values $\mathrm{AB} \rightarrow$ Sexual frequency & -.07 & .24 & .03 & .65 & .03 & .24 & .01 & .92 \\
\hline Chastity values $\mathrm{SB} \rightarrow$ Sexual frequency & -.06 & .28 & .07 & .10 & $.05^{*}$ & .03 & .03 & .64 \\
\hline Chastity values $\mathrm{AB} \rightarrow$ Sexual satisfaction & -.08 & .17 & -.11 & .06 & -.02 & .61 & -.06 & .32 \\
\hline Chastity values SB $\rightarrow$ Sexual satisfaction & -.01 & .88 & $.11^{*}$ & .01 & $.07^{* * *}$ & .004 & .03 & .55 \\
\hline
\end{tabular}

Note. Chastity values $\mathrm{AB}=$ belief that abstinence from premarital sex is best; Chastity values $\mathrm{SB}=$ belief that sex in marriage is a bonding experience. ${ }^{*} p<.05 .{ }^{* * *} p<.01 .{ }^{* * *} p<.001$. 
honey, \& Pargament, 2011; Murray-Swank, Pargament, \& Mahoney, 2005). On the contrary, chastity values did not predict sexual satisfaction among married couples (in general, or within a particular religious group). This may be because of perceived mixed messages regarding sexuality in religious communities, where sex is seen as bad before marriage but good after marriage (Regnerus, 2007). This complex transition process for religious people warrants further study.

The analyses also found that, in most cases, chastity values mediated relations between religiosity and outcomes. Thus, one way religiosity may promote chaste living (sexual abstinence prior to marriage and sexual intimacy within marriage) is through teaching chastity values. This confirms prior work on values as mediators of religious influence (Hardy \& Carlo, 2005), as well as specifically on the mediating role of views about sexuality in linking religiosity to sexual outcomes (Aalsma et al., 2013; Lefkowitz et al., 2004; Meier, 2003). However, this was the first study to demonstrate the role of chastity values in mediating links between religiosity and psychological well-being (i.e., unhappiness). Further, although prior studies have linked religiosity to satisfaction and frequency of sex in marriage, this was the first to show chastity values as a potential mechanism. Nevertheless, the indirect effects in the present study were somewhat weak. Thus, it is likely that multiple processes are involved in religious influence, such as providing positive role models and peers, facilitating self-control, and inducing social control (Smith, 2003). Further research is needed to examine the relative and interactive roles of such processes.

Lastly, we also found the mean differences between religious affiliations, reported in the preliminary analyses, to be illuminating. Among single young adults and married adults, LDS participants showed the highest religiosity and strongest chastity values, followed by Protestants, then Catholics, then unaffiliated. This pattern also held true for single adult unhappiness (although LDS and Protestants were not significantly different), risk taking, and sexual risk taking, with relative healthy functioning going in the order of LDS, Protestant, Catholic, and unaffiliated. This pattern is in line with prior studies comparing religious affiliations on religiosity, well-being, and psychosocial functioning (Smith \& Snell, 2009). The pattern for married adult sexual satisfaction and frequency was slightly different, with LDS showing the highest satisfaction and frequency, followed by Protestants, then unaffiliated, and then Catholics. Perhaps perceived mixed messages about sexuality are highest in the Catholic Church, while LDS and Protestant faiths are able to more successfully convey positive views of sexuality (Regnerus, 2007). More work is needed to further unpack these religious affiliation differences.

\section{Limitations and Future Directions}

The present study had a number of methodological limitations that should be considered when interpreting the results. First, the data were cross-sectional, limiting our ability to establish temporal ordering and causality. For instance, it is possible that those who do not believe chastity or follow chastity norms are less likely to be religiously involved (Vasilenko \& Lefkowitz, 2014). Longitudinal studies are needed spanning from adolescence to adulthood. Second, the data sets in the present study used a limited range of measures of religiosity, chastity values, and outcomes. Future studies should capture other aspects of religiosity (e.g., religious internalization), use other indexes of chastity values (e.g., sanctification of sexuality), and predict other outcomes (e.g., social connectedness). For example, in the present study we focused on proscriptive sexuality (avoiding unhealthy sexual behaviors) among single young adults and prescriptive sexuality (engaging in healthy sexual behaviors) among married couples. Future studies should conversely look at prescriptive sexuality among adolescents and single young adults (e.g., satisfaction with sex in committed relationships prior to marriage) and proscriptive sexuality among married adults (e.g., avoiding extramarital sex). Third, the measures were all self-report survey measures, and in some cases included only a single item. While a potential limitation, some scholars have noted that psychological constructs may be properly assessed with single-item assessments (e.g., Bergkvist \& Rossiter, 2007; Fisher, Matthews, \& Gibbons, 2016; Zimmerman et al., 2006). Future studies should extend this work by including other well-validated measures, with measurement modalities such as other-report, behavioral, and physiological. Fourth, the samples in the present study were large, but in some ways limited in diversity. In particular, almost all participants were heterosexual. Thus, future work should explore implications of links between religion and chastity for those in the lesbian, gay, bisexual, transgender, and queer community. Also, the samples, particularly the single young adult sample, were heavily female. Although we controlled for gender in the primary analyses, future research could examine whether processes linking religiosity to chastity values and outcomes differ between men and women. Additionally, we were not able to differentiate between Evangelical and mainline Protestant faiths, or include comparisons to other religions such as the Jewish and Muslim faiths. Fifth, some of the effects were small. Future research should explore whether there are other more salient psychosocial and sexual outcomes of chastity values.

\section{Conclusion}

Religions teach proscriptions and prescriptions, and have structures in place to motivate and enable people to follow those teachings (McMurdie et al., 2013; Regnerus, 2007). Sexuality within religious communities is a particularly salient issue because it pertains to some of the most strongly enforced proscriptions (e.g., avoiding premarital sex) and most strongly encouraged prescriptions (e.g., be sexually intimate within marriage as a way to create children and bond as a couple; Catechism of the Catholic Church, 1997). The purpose of the present study was to present philosophical, theological, and psychological ideas linking religiosity to chastity as a virtue, and to provide empirical evidence to support those ideas. Theologically, sexuality is held as sacred, and thus prohibited outside of married but seen as supremely meaningful within marriage (Catechism of the Catholic Church, 1997). Philosophically, chastity is seen as both a virtue of self-control and a virtue of attachment (Carr, 2007). Psychologically, religious doctrines and norms may lead people to have more conservative attitudes about sexuality, which, in turn, might lead to healthier sexuality and psychosocial functioning (Aalsma et al., 2013; Lefkowitz et al., 2004; Meier, 2003). Indeed, our results confirm and extend evidence for these ideas. In a large sample of single young adults we showed that religiosity was linked to greater sexual and psychosocial health via chastity values. Similarly, 
among a large sample of married adults we demonstrated that religiosity was predictive of greater sexual frequency and satisfaction via chastity values (with the exception that belief in premarital sexual abstinence was not related to sexual satisfaction). Thus, it seems that one way religious communities might promote healthy sexuality and psychosocial functioning is by teaching beliefs about chastity. Put differently, by taking a virtue-based approach to sexuality as chastity, religious communities may be able to help people avoid sexual relations before marriage, engage in healthy sexuality within marriage, and be happy about it.

\section{References}

Aalsma, M. C., Woodrome, S. E., Downs, S. M., Hensel, D. J., Zimet, G. D., Orr, D. P., \& Fortenberry, J. D. (2013). Developmental trajectories of religiosity, sexual conservatism and sexual behavior among female adolescents. Journal of Adolescence, 36, 1193-1204. http://dx .doi.org/10.1016/j.adolescence.2013.08.005

Arakawa, D. R., Flanders, C. E., Hatfield, E., \& Heck, R. (2013). Positive psychology: What impact has it had on sex research publication trends? Sexuality \& Culture: An Interdisciplinary Quarterly, 17, 305-320. http://dx.doi.org/10.1007/s12119-012-9152-3

Atkins, D. C., \& Kessel, D. E. (2008). Religiousness and infidelity: Attendance, but not faith and prayer, predict marital fidelity. Journal of Marriage and Family, 70, 407-418. http://dx.doi.org/10.1111/j.17413737.2008.00490.x

Barkan, S. E. (2006). Religiosity and premarital sex in adulthood. Journal for the Scientific Study of Religion, 45, 407-417. http://dx.doi.org/10 $.1111 / \mathrm{j} .1468-5906.2006 .00315 . x$

Barry, C. M., Willoughby, B. J., \& Clayton, K. (2015). Living your faith: Associations between family and personal religious practices and emerging adults' sexual behavior. Journal of Adult Development, 22, 159-172. http://dx.doi.org/10.1007/s10804-015-9209-2

Bergkvist, L., \& Rossiter, J. R. (2007). The predictive validity of multipleitem versus single-item measures of the same constructs. Journal of Marketing Research, 44, 175-184. http://dx.doi.org/10.1509/jmkr.44.2 .175

Brechting, E. H., \& Carlson, C. R. (2015). Religiousness and alcohol use in college students: Examining descriptive drinking norms as mediators. Journal of Child \& Adolescent Substance Abuse, 24, 1-11. http://dx.doi .org/10.1080/1067828X.2014.958000

Brown, T. A. (2006). Confirmatory factor analysis for applied research. New York, NY: Guilford Press.

Busby, D. M., Holman, T. B., \& Taniguchi, N. (2001). RELATE: Relationship evaluation of the individual, family, cultural, and couple contexts. Family Relations, 50, 308-316. http://dx.doi.org/10.1111/j.17413729.2001.00308.x

Callister, T. R. (2014, March). The Lord's standard of morality. Ensign. Retrieved from https://www.lds.org/ensign/2014/03/the-lords-standardof-morality?lang =eng

Carpenter, C. J. (2012). Meta-analyses of sex differences in responses to sexual versus emotional infidelity: Men and women are more similar than different. Psychology of Women Quarterly, 36, 25-37. http://dx.doi .org/10.1177/0361684311414537

Carr, D. (2007). On the prospects of chastity as a contemporary virtue. In R. Halwani (Ed.), Essays on sexuality, virtue, and the good life (pp. 89-100). New York, NY: Palgrave.

Catechism of the Catholic Church (2nd ed.). (1997). Washington, DC: United States Conference of Catholic Bishops. Retrieved from http:// www.usccb.org/beliefs-and-teachings/what-we-believe/catechism/ catechism-of-the-catholic-church/epub/index.cfm

DeMaris, A. (2013). Burning the candle at both ends: Extramarital sex as a precursor of marital disruption. Journal of Family Issues, 34, 14741499. http://dx.doi.org/10.1177/0192513X12470833
Donnelly, D. A. (1993). Sexually inactive marriages. Journal of Sex Research, 30, 171-179. http://dx.doi.org/10.1080/00224499309551698

Fisher, G. G., Matthews, R. A., \& Gibbons, A. M. (2016). Developing and investigating the use of single-item measures in organizational research. Journal of Occupational Health Psychology, 21, 3-23. http://dx.doi.org/ 10.1037/a0039139

Ford, J. A., \& Hill, T. D. (2012). Religiosity and adolescent substance use: Evidence from the national survey on drug use and health. Substance Use \& Misuse, 47, 787-798. http://dx.doi.org/10.3109/10826084.2012 .667489

Galinsky, A. M., \& Waite, L. J. (2014). Sexual activity and psychological health as mediators of the relationship between physical health and marital quality. The Journals of Gerontology, Series B: Psychological Sciences and Social Sciences, 69, 482-492. http://dx.doi.org/10.1093/ geronb/gbt165

Garcia, J. R., Reiber, C., Massey, S. G., \& Merriwether, A. M. (2012). Sexual hookup culture: A review. Review of General Psychology, 16, 161-176. http://dx.doi.org/10.1037/a0027911

Grov, C., Starks, T. J., Rendina, H. J., \& Parsons, J. (2014). Rules about casual sex partners, relationship satisfaction, and HIV risk in partnered gay and bisexual men. Journal of Sex \& Marital Therapy, 40, 105-122. http://dx.doi.org/10.1080/0092623X.2012.691948

Hardy, S. A., \& Carlo, G. (2005). Religiosity and prosocial behaviors in adolescence: The mediating role of prosocial values. Journal of Moral Education, 34, 231-249. http://dx.doi.org/10.1080/03057240500127210

Hardy, S. A., Steelman, M. A., Coyne, S. M., \& Ridge, R. D. (2013). Adolescent religiousness as a protective factor against pornography use. Journal of Applied Developmental Psychology, 34, 131-139. http://dx .doi.org/10.1016/j.appdev.2012.12.002

Harris, J. (1997). I kissed dating goodbye. Colorado Springs, CO: Multnomah Books.

Hernandez, K. M., Mahoney, A., \& Pargament, K. I. (2011). Sanctification of sexuality: Implications for newlyweds' marital and sexual quality. Journal of Family Psychology, 25, 775-780. http://dx.doi.org/10.1037/ a0025103

Iveniuk, J., O'Muircheartaigh, C., \& Cagney, K. A. (2016). Religious influence on older Americans' sexual lives: A nationally-representative profile. Archives of Sexual Behavior. Archives of Sexual Behavior, 45, 121-131.

Jankowski, P. J., Hardy, S. A., Zamboanga, B. L., \& Ham, L. S. (2013). Religiousness and hazardous alcohol use: A conditional indirect effects model. Journal of Adolescence, 36, 747-758. http://dx.doi.org/10.1016/ j.adolescence.2013.06.001

Kisa, S., Zeyneloğlu, S., Yilmaz, D., \& Güner, T. (2014). Quality of sexual life and its effect on marital adjustment of Turkish women in pregnancy. Journal of Sex \& Marital Therapy, 40, 309-322. http://dx.doi.org/10 .1080/0092623X.2012.751071

Lefkowitz, E. S., Gillen, M. M., Shearer, C. L., \& Boone, T. L. (2004). Religiosity, sexual behaviors, and sexual attitudes during emerging adulthood. Journal of Sex Research, 41, 150-159. http://dx.doi.org/10 $.1080 / 00224490409552223$

MacIntyre, A. (2007). After virtue (3rd ed.). Notre Dame, IN: University of Notre Dame Press.

McMurdie, C. A., Dollahite, D. C., \& Hardy, S. A. (2013). Adolescent and parent perceptions of religious influence: The role of religious beliefs and practices on relationships, life direction, and character development. Journal of Psychology and Christianity, 32, 192-205.

Meier, A. M. (2003). Adolescents' transition to first intercourse, religiosity, and attitudes about sex. Social Forces, 81, 1031-1052. http://dx.doi .org/10.1353/sof.2003.0039

Murray-Swank, N. A., Pargament, K. I., \& Mahoney, A. (2005). At the crossroads of sexuality and spirituality: The sanctification of sex by college students. International Journal for the Psychology of Religion, 15, 199-219. http://dx.doi.org/10.1207/s15327582ijpr1503_2 
Muthén, L. K., \& Muthén, B. O. (1998-2012). Mplus user's guide (7th ed.). Los Angeles, CA: Author.

Nucci, L., \& Turiel, E. (1993). God's word, religious rules, and their relation to Christian and Jewish children's concepts of morality. Child Development, 64, 1475-1491. http://dx.doi.org/10.2307/1131547

O'Donnell, L., O'Donnell, C. R., \& Stueve, A. (2001). Early sexual initiation and subsequent sex-related risks among urban minority youth: The reach for health study. Family Planning Perspectives, 33, 268-275. http://dx.doi.org/10.2307/3030194

Olmstead, S. B., Roberson, P. N. E., Pasley, K., \& Fincham, F. D. (2015). Hooking up and risk behaviors among first semester college men: What is the role of precollege experience? Journal of Sex Research, 52, 186-198. http://dx.doi.org/10.1080/00224499.2013.843147

Regnerus, M. (2007). Forbidden fruit: Sex and religion in the lives of American teenagers. New York, NY: Oxford University Press. http://dx .doi.org/10.1093/acprof:oso/9780195320947.001.0001

Regnerus, M. (2011). Premarital sex in America: How young Americans meet, mate, and think about marrying. New York, NY: Oxford University Press.

Rostosky, S. S., Wilcox, B. L., Wright, M. L. C., \& Randall, B. A. (2004). The impact of religiosity on adolescent sexual behavior: A review of the evidence. Journal of Adolescent Research, 19, 677-697. http://dx.doi .org/10.1177/0743558403260019

Sassler, S., Addo, F. R., \& Lichter, D. T. (2012). The tempo of sexual activity and later relationship quality. Journal of Marriage and Family, 74, 708-725. http://dx.doi.org/10.1111/j.1741-3737.2012.00996.x

Shaw, S. A., \& El-Bassel, N. (2014). The influence of religion on sexual HIV risk. AIDS and Behavior, 18, 1569-1594. http://dx.doi.org/10 .1007/s10461-014-0714-2

Smith, C. (2003). Theorizing religious effects among American adolescents. Journal for the Scientific Study of Religion, 42, 17-30. http://dx .doi.org/10.1111/1468-5906.t01-1-00158

Smith, C., \& Denton, M. L. (2005). Soul searching: The religious and spiritual lives of American teenagers. New York, NY: Oxford University Press. http://dx.doi.org/10.1093/019518095X.001.0001
Smith, C., \& Snell, P. (2009). Souls in transition: The religious and spiritual lives of emerging adults. New York, NY: Oxford University Press. http://dx.doi.org/10.1093/acprof:oso/9780195371796.001.0001

Teachman, J. (2003). Premarital sex, premarital cohabitation and the risk of subsequent marital dissolution among women. Journal of Marriage and Family, 65, 444-455. http://dx.doi.org/10.1111/j.1741-3737.2003 .00444.x

The Church of Jesus Christ of Latter-Day Saints. (2011). Chapter 39: The law of chastity. In Gospel principles. Salt Lake City, Utah: LDS Church. Retrieved from https://www.lds.org/manual/gospel-principles/chap.-39the-law-of-chastity?lang =eng

Uecker, J. E. (2008). Religion, pledging, and the premarital sexual behavior of married young adults. Journal of Marriage and Family, 70, 728-744. http://dx.doi.org/10.1111/j.1741-3737.2008.00517.x

Vasilenko, S. A., \& Lefkowitz, E. S. (2014). Changes in religiosity after first intercourse in the transition to adulthood. Psychology of Religion and Spirituality, 6, 310-315. http://dx.doi.org/10.1037/a0037472

Village, A., Williams, E., \& Francis, L. J. (2010). Living in sin? Religion and cohabitation in Britain 1985-2005. Marriage \& Family Review, 46, 468-479. http://dx.doi.org/10.1080/01494929.2010.528710

Walker, L. J., Pitts, R. C., Hennig, K. H., \& Matsuba, M. K. (1995). Reasoning about morality and real-life moral problems. In M. Killen \& D. Hart (Eds.), Morality in everyday life (pp. 371-407). New York, NY: Cambridge University Press.

Zimmerman, M., Ruggero, C. J., Chelminski, I., Young, D., Posternak, M. A., Friedman, M., . . . Attiullah, N. (2006). Developing brief scales for use in clinical practice: The reliability and validity of single-item self-report measures of depression symptom severity, psychosocial impairment due to depression, and quality of life. The Journal of Clinical Psychiatry, 67, 1536-1541. http://dx.doi.org/10.4088/JCP.v67n1007

Received April 1, 2016

Revision received July 18, 2016 Accepted August 23, 2016 